United States have now taken definite action to remedy this state of affairs. The American Ophthalmological Society, the American Academy of Ophthalmology and Oto-Laryngology, and the Section of Ophthalmology of the American Medical Association, some time ago appointed committees to consider the question, and it has been decided to hold a meeting in Washington about the end of April, 1922. . Application for membership in the Congress, with the fee of ten dollars, should be sent to Dr. W. R. Parker, David Whitney Building, Detroit, Michigan, and it may be noted that it is proposed to remit the dues from those outside America who make the journey to attend the Congress. Topics for discussion, offers of papers, and suggestions should be sent to Dr. Edward Jackson, 318, Majestic Building, Denver, Colorado. The officials of the Congress include Dr. E. C. Ellett, chairman of Committee on Organiżation, of Memphis, Tenn., Dr. William H. Wilmer, of Washington, D.C., chairman of the Committee of Arrangements, and Dr. Lee Masten Francis, of Buffalo, chairman of the Committee on Finance. We wish the meeting every success. At this juncture the American action is opportune and to be welcomed. It is to be hoped, however, that when circumstances permit, the Congress will fall into series with former International Congresses, and be conducted by a committee upon which all eligible nations are represented.

\title{
Departmental Committee on Blindness
}

Readers will be glad to learn that a committee has been appointed by the Minister of Health to investigate and report upon the causes of blindness, as well as of defective sight adequate to impair economic efficiency, and to suggest measures for prevention. The following have been asked to serve: Right Hon. G. H. Roberts, M.P. (chairman); Mr. Stephen Walsh, M.P.; Mr. N. Bishop Harman; Mr. J. B. Lawford; Mr. G. F. Mowatt ; Mrs. Wilton Phipps; Mr. J. Herbert Parsons (representing the Royal College of Surgeons); Dr. James Taylor (representing the Royal College of Physicians); Mr. J. C. Bridge (representing the Home Office); Dr. A. Eichholz (representing the Board of Education); Mr. J. S. Nicholson (representing the Ministry of Labour), Mr. W. M. Stone (representing the Scottish Office); and Mr. E. D. Macgregor (representing the Ministry of Health). A representative of the Medical Research Council will be appointed later. Joint Secretaries: Dr. R. A. Farrar and Mr. P. N. R. Butcher, Ministry of Health, Whitehall, London, S.W.1. From most points of view the Committee is sufficiently representative, and will doubtless accomplish excellent work. It is, however, open 
to criticism from two points of view. In the first place, that important and useful body, the Council of British Ophthalmologists, is not directly represented, as it undoubtedly should be. Secondly, although the reference expressly includes causes that may lead to a defect in sight such as to impair economic efficiency, yet we miss the name of any member directly entitled by experience to speak upon this point. Take miners' nystagmus, for example, a condition that costs this country over a million pounds a year, can any member of the committee claim a first-hand acquaintance with that disabling ailment? Fortunately, even at the eleventh hour, it is not too late to remedy the second omission, if only the Medical Research Council sees proper to send as its representative one who has practical knowledge of occupational disability.

\section{The Moorfields Appeal}

The Royal London Ophthalmic Hospital, first established in Charterhouse Square in 1804, as the London Dispensary for Curing Diseases of the Eye and Ear, has several times changed its name. That by which it is most generally known throughout the Ophthalmic world is "The Moorfields Eye Hospital." It received the dignity of being converted into a Royal Institution in 1836 when Queen Victoria, then the Princess Victoria, together with her mother, the Duchess of Kent, became its patronesses. Since then the Royal family have several times manifested their interest in the Hospital. King Edward VII, when Prince of Wales, laid the foundation of the present building, which was opened by King George and Queen Mary, when Duke and Duchess of York, in 1899. Now, the President of the Hospital, Prince Arthur of Connaught, has issued an appeal for a fund of $£ 100,000$ : (I) To enable it to pay off a heavy debt to its bankers. (II) To enable it to extend its laboratory accommodation for purposes of clinical and pathological research. (III) To supply adequately paid assistants to the Honorary Medical Staff, which will liberate them from much of the routine work which they now have to perform, and allow of them devoting more of their time to clinical instruction and research for which they are so eminently qualified. (IV) To supply adequate accommodation for the nursing staft, not only those who carry on the general work of the Hospital, but also those desirous of obtaining a special training in the nursing of cases of diseases of the eye.

The Hospital justly claims to be the parent of all similar institutions throughout the English speaking world, and it is issuing an appeal, not only in this country, but also in the United States of America, in the Dominion of Canada, and in the Empire of India. 